\title{
Skala TAI-G Untuk Kecemasan Menghadapi Ujian Sekolah Pada Siswa Sekolah Menengah Atas
}

\author{
Rayinda Faizah(1) \\ Universitas Muhammadiyah Magelang \\ Rayinda.faizah@ummgl.ac.id \\ Shallza Millinia Alqisty(2) \\ Universitas Muhammadiyah Magelang \\ Fathonah(3) \\ Universitas Muhammadiyah Magelang \\ Indra Alvianita(4) \\ Universitas Muhammadiyah Magelang \\ Hasnaa' Zahuna Nayu(5) \\ Universitas Muhammadiyah Magelang \\ DOI: 10.23917/varidika.v32i1.11155
}

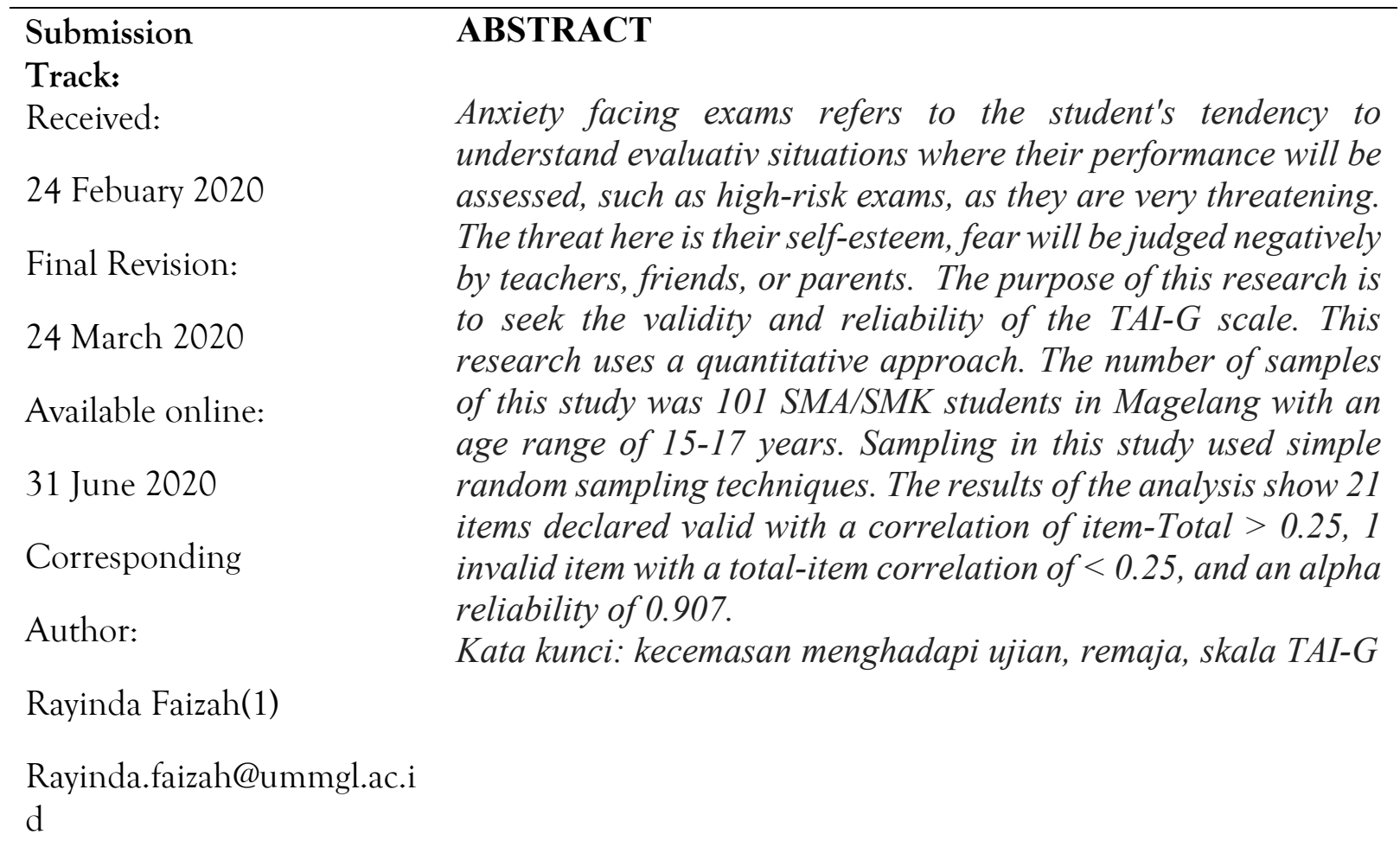




\section{PENDAHULUAN}

Masa remaja adalah suatu periode transisi dalam rentang kehidupan manusia, yang menjembatani masa kanak-kanak dengan masa dewasa (Santrock, 2011:402). Dalam suatu kehidupan, seseorang pasti akan dihadapkan pada suatu masalah yang membuat seseorang tersebut cemas dan hal-hal tersebut tidak dapat dihindari. Kecemassan adalah suatu keadaan aprehensi / keadaan khawatir yang mengeluhkan sesuatu yang buruk akan segera terjadi (Nevid et al., 2013:163). Kecemasan dapat dipandang sebagai reaksi emosional yang tidak menyenangkan yang dihasilkan dari persepsi atau penilaian terhadap sumber kecemasan sebagai ego yang mengancam (Mukhlis \& Koentjoro, 2014). Berdasarkan data Riskesdas tahun 2013 menyatakan bahwa prevalensi nasional pada gangguan kecemasan yang dialami oleh remaja di Indonesia berusia kurang lebih 15 tahun sebanyak 37 ribu penduduk, dan di Jawa Tengah prevalensi gangguan kecemasan pada remaja sekitar 4,7 \% (Departemen Kesehatan RI, 2013). Gangguan kecemasan pada remaja, biasanya terjadi karena beberapa keadaan yaitu, masalah sekolah (saat ujian) (Kendall, 2008). Faktor-faktor yang mempengaruhi kecemasan adalah 1. Pengalaman negatif, 2. Pikiran yang tidak rasional, 3. Generalisasi yang tidak tepat (Nevid et al., 2013:164). Dan menurut Hurlock, kecemasan dapat dipengaruhi oleh beberapa faktor yaitu, usia, jenis kelamin, status kesehatan, pengalaman dan besar kecilnya stressor (Hurlock, 1992).

Daroji (2015:184) mengatakan kecemasan yang dialami siswa merupakan suatu bentuk pemikiran-pemikiran siswa yang mengganggu dan menjadi suatu permasalahan bagi siswa itu sendiri. Kecemasan pada siswa seringkali disebabkan oleh tekanan dalam menghadapi ujian. Ujian merupakan bagian yang penting bagi dunia pendidikan supaya bisa mengukur kemampuan siswa di SMA/SMK. Berdasarkan penelitian dari Agustiar dan Asmi bahwa takut gagal dalam ujian akhir dianggap sebgai ancaman bagi siswa yang memicu kecemasan (Sari et al., 2017:37). Aspek-aspek yang mempengaruhi kecemasan yaitu: 1. Kekhawatiran (worry), 2. Emosionalitas (emosionality), 3. Gangguan (Interference), 4. Kurang Percaya Diri (Lack of Confedence) (Harpell \& Andrews, 2012:518). Kurang percaya diri akan menimbulkan kecemasan pada siswa saat menghadapi ujian (Mingers \& Standing, 2018:5). Ujian sekolah yang terkadang dipandang menakutkan dan mengancam akan memunculkan penilaian negatif terhadap US, sehingga menimbulkan rasa ketakutan, kehawatiran, dan perasaan tidak berdaya dalam menghadapi situasi ujian (Anggarawati \& Hakim, 2018:476). 
Kecemasan ujian adalah respon kecemasan yang berlebihan seperti depresi, gugup, dan pemikiran yang tidak rasional (Rasor \& Rasor, 1998:4). Kecemasan menghadapi ujian mengacu pada kecenderungan siswa untuk memahami situasi evaluatif dimana kinerja mereka akan dinilai, seperti ujian beresiko tinggi, karena sangat mengancam. Ancaman disini merupakan harga diri mereka, ketakutan akan dihakimi secara negative oleh guru, teman, atau orang tua (Putwain, 2008:1). Seringkali siswa mengalami kecemasan dan ketakutan saat menghadapi ujian serta kurangnya persiapan yang matang untuk menghadapi ujian. Hal ini sejalan dengan studi pendahuluan yang dilakukan peneliti kepada beberapa siswa di Magelang. Hasil wawancara menunjukkan bahwa dari beberapa siswa tersebut mengalami sakit perut, pusing, keringat dingin, jantung berdegub kencang. Mereka juga menyampaikan terkadang mempunyai pikiran akan gagal, dan sulit untuk berkonsentrasi. Hal ini juga didukung dengan apa yang dikemukakan oleh Nevid, ciri-ciri kecemasan diantaranya yaitu gangguan sakit perut atau mual, panas dingin, diare, rasa sensitif keringat berlebih, khawatir akan suatu hal yang menakutkan, ketakutan akan tidak bisa menangani masalah, tidak mampu menghilangkan pikiran-pikiran yang mengganggu, sulit berkonsentrasi atau fokus (Nevid et al., 2013:164).

Berdasarkan pemaparan diatas, maka peneliti ingin melakukan adaptasi terhadap skala TAI-G. Yang mana skala TAI-G adalah ukuran multidimensi yang terdiri dari empat subskala: khawatir, emosional, tidak percaya diri, dan gangguan. Khawatir mengacu pada manifestasi kognitif kecemasan atas kinerja, sedangkan emosionalitas mengacu pada reaksi emosional dan otonom dalam kaitannya dengan pemeriksaan. Pengembangan TAI-G termasuk penambahan dari kurangnya subskala kepercayaan, yang didefinisikan oleh Hodapp (1996) sebagai keyakinan peserta tes dalam ketidakmampuannya untuk berkinerja baik dalam ujian yang akan datang. Subskala gangguan juga ditambahkan, yang berkaitan dengan keberadaan pemikiran yang mengganggu kinerja saat bekerja dan bukan merupakan komponen kekhawatiran semata (mis., Disibukkan dengan pemikiran umum yang menyebabkan gangguan). Terakhir, TAI-G berisi item yang merujuk hanya pada pengalaman individu selama situasi pemeriksaan (Mowbray et al., 2015:121). Sehingga bisa digunakan sebagai skala assessment terhadap kecemasan siswa sebelum menghadapi ujian. Penelitian ini bertujuan untuk mencari validitas dan reliabilitas dari skala TAI-G. 


\section{METODE PENELITIAN}

Penelitian menggunakan pendekatan kuantitatif deskriptif. Sampel penelitian ini adalah siswa SMA/SMK di Magelang dengan rentang usia 15-17 tahun. Teknik pengambilan sample yang digunakan menggunakan simple random sampling. Partisipan penelitian berjumlah 101 yang terdiri dari 80 perempuan dan 21 laki-laki. Variabel bebas dalam penelitian ini adalah kecemasan. Definisi kecemasan yakni kekhawatiran atau ketegangan berupa perasaaan tegang, cemas, dan emosi yang dialami seseorang.

Metode pengumpulan data yang dilakukan peneliti menggunakan German Test Anxiety Inventory (TAI-G) (Harpell \& Andrews, 2012:518). Analisis data dalam penelitian iini menggunakan program SPSS for windows versi 23. Penelitian ini telah dilaksanakan di daerah wilayah Magelang pada bulan Desember 2019-Januari 2020. Langkah pertama dalam penelitian ini adalah menerjemahkan skala TAI-G ke dalam Bahasa Indonesia dengan bantuan dosen psikologi, dilanjutkan dengan penyebaran skala dan dilanjutkan dengan analisis data menggunakan Reliability Analysis dengan bantuan SPSS untuk mengetahui validitas dan reliabilitas skala.

\section{HASIL DAN PEMBAHASAN}

Pada penelitian ini peneliti melakukan dua putaran dalam analisis data untuk memperoleh hasil yang memuaskan. Pada putaran pertama diperoleh nilai reliabilitas alpha sebesar 0.888 dan 22 item dinyatakan valid karena memperoleh nilai koefisien korelasi item total $>0.25$, dan 8 item memperoleh nilai kurang $<0.25$. Kemudian dilanjutkan dengan perhitungan putaran kedua dan diperoleh nilai reliabilitas alpha sebesar 0.907. Pembahasan penelitian diuraikan sebagai berikut.

Tabel 1. Aspek Pernyataan

\begin{tabular}{|c|c|c|}
\hline Aspek & Pernyataan & $\begin{array}{l}\text { No Butir } \\
\text { Item }\end{array}$ \\
\hline \multirow[t]{4}{*}{ Worry } & Saya berpikir betapa pentingnya ujian bagi saya & 2 \\
\hline & Saya khawatir saat menghadapi pemeriksaan hasil ujian & 6 \\
\hline & $\begin{array}{l}\text { Saya memikirkan konsekuensi dari nilai yang kurang } \\
\text { memuaskan }\end{array}$ & 9 \\
\hline & $\begin{array}{l}\text { Saya bertanya pada diri sendiri apakah kinerja saya } \\
\text { cukup baik }\end{array}$ & 10 \\
\hline
\end{tabular}




\begin{tabular}{|c|c|c|}
\hline Aspek & Pernyataan & $\begin{array}{l}\text { No Butir } \\
\text { Item }\end{array}$ \\
\hline & $\begin{array}{l}\text { Saya memikirkan pentingnya mendapatkan hasil ujian } \\
\text { yang baik }\end{array}$ & 14 \\
\hline & Saya merasa khawatir dengan hasil ujian & 17 \\
\hline & Saya tidak percaya diri saat menjawab ujian & 23 \\
\hline & $\begin{array}{l}\text { Saya memikirkan apa yang akan terjadi jika saya tidak } \\
\text { melakukannya dengan baik }\end{array}$ & 27 \\
\hline \multirow[t]{8}{*}{ Emotionality } & Saya merasa hampa ketika menghadapi ujian & 3 \\
\hline & Saya merasa tegang sebelum menghadapi ujian & 7 \\
\hline & Saya merasa gelisah saat menghadapi ujian & 12 \\
\hline & $\begin{array}{l}\text { Jantung saya berdegub kencang sebelum menghadapi } \\
\text { ujian }\end{array}$ & 16 \\
\hline & Saya merasa cemas saat menghadapi ujian & 18 \\
\hline & Saya gemetar ketakutan dalam menghadapi ujian & 22 \\
\hline & Saya merasa kewalahan dalam menghadapi ujian & 25 \\
\hline & Saya merasa kesal sebelum menghadapi ujian & 28 \\
\hline $\begin{array}{c}\text { Lack of } \\
\text { Confidence }\end{array}$ & $\begin{array}{l}\text { Saya yakin bahwa saya akan melakukannya dengan } \\
\text { baik }\end{array}$ & 29 \\
\hline \multirow[t]{6}{*}{ Interference } & Saya memiliki keyakinan pada kinerja saya sendiri & 8 \\
\hline & Saya terganggu dengan pikiran-pikiran lain & 11 \\
\hline & Saya tidak bisa berkonsentrasi & 15 \\
\hline & $\begin{array}{l}\text { Saya melupakan hal lain karena fokus pada masalah } \\
\text { pribadi saya }\end{array}$ & 19 \\
\hline & Saya tidak bisa berkonsentrasi & 24 \\
\hline & Saya merasa semuanya sangat sulit bagi saya & 30 \\
\hline \multicolumn{2}{|c|}{$\begin{array}{lll} & \text { Jumlah }\end{array}$} & 22 \\
\hline
\end{tabular}


Tabel 2. Hasil Perhitungan

\begin{tabular}{|c|c|c|c|c|}
\hline & $\begin{array}{c}\text { Scale Mean } \\
\text { if Item } \\
\text { Deleted }\end{array}$ & $\begin{array}{c}\text { Scale } \\
\text { Variance if } \\
\text { Item Deleted }\end{array}$ & $\begin{array}{l}\text { Corrected } \\
\text { Item-Total } \\
\text { Correlation }\end{array}$ & $\begin{array}{c}\text { Cronbach's } \\
\text { Alpha if Item } \\
\text { Deleted }\end{array}$ \\
\hline item2 & 57.9802 & 121.720 & .279 & .908 \\
\hline item3 & 58.8614 & 115.221 & .530 & .903 \\
\hline item5 & 58.4950 & 112.832 & .628 & .900 \\
\hline item6 & 58.3960 & 112.942 & .637 & .900 \\
\hline item7 & 58.5743 & 112.207 & .666 & .899 \\
\hline item9 & 58.1683 & 118.101 & .410 & .905 \\
\hline item 10 & 58.1287 & 117.993 & .442 & .905 \\
\hline item 11 & 58.2673 & 114.238 & .580 & .901 \\
\hline item 12 & 58.6040 & 112.282 & .672 & .899 \\
\hline item14 & 57.8812 & 121.706 & .326 & .906 \\
\hline item 15 & 58.6931 & 115.455 & .539 & .902 \\
\hline item 16 & 58.9208 & 113.014 & .642 & .900 \\
\hline item 17 & 58.2178 & 114.112 & .657 & .900 \\
\hline item 18 & 58.6634 & 111.706 & .771 & .897 \\
\hline item 22 & 59.3663 & 116.714 & .524 & .903 \\
\hline item 23 & 58.7327 & 116.778 & .494 & .903 \\
\hline item 24 & 58.7822 & 115.812 & .529 & .903 \\
\hline item 25 & 58.8416 & 116.675 & .496 & .903 \\
\hline item 27 & 58.0792 & 118.574 & .436 & .905 \\
\hline item 28 & 59.0000 & 115.580 & .501 & .903 \\
\hline item 29 & 58.1188 & 124.406 & .114 & .910 \\
\hline item 30 & 59.0891 & 113.422 & .570 & .902 \\
\hline
\end{tabular}


Tabel 3. Reliability Statistics

\begin{tabular}{|r|r|}
\hline $\begin{array}{c}\text { Cronbach's } \\
\text { Alpha }\end{array}$ & N of Items \\
\hline .907 & 22 \\
\hline
\end{tabular}

Dari penelitian ini, ditentukan bahwa empat aspek TA paling baik diterapkan pada sampel dalam sistem penilaian skala, menggunakan versi TAI-G yang diperkecil. Penelitian dimasa depan harus bertujuan untuk menguatkan temuan ini dan mengembangkan data normatif dibeberapa penilaian. Untuk menentukan konsistensi internal, alpha crobanch dihitung untuk item dari masing-masing subskala dan skor total sampel.hasil ini menunjukkan bahwa kekhawatiran dan kepercayaan diri terkait tes harus diberikan perhatian khusus, dan kemungkinan harus diperhaatikan sejak usia dini. Hal inii didukung dengan penelitian yang dilakukan oleh Harpell bahwa dari keempat aspek tersebut kekhawatiran dianggap sebagai yang paling kuat dari empat faktor, secara klinis signifikan bahwa semua partisipan mengukur aspek ini secara bersamaan. Khawatir secara konsisten dapat meningkatkan penilaian knilis relatif terhadaap laporan yang bertentangan (Harpell \& Andrews, 2012:518). Dalam penelitian Mowbray juga dikatakan temuan-temuan dari penelitian ini adalah konsisten dengan penelitian sebelumnya yang mendukung empat faktor konseptualisasi TA (Mowbray et al., 2015:126).

\section{SIMPULAN}

Kesimpulannya adalah hasil penelitian ini menunjukan bahwa skala TAI-G terbukti mempunyai reliabilitas dan validitas yang baik.

\section{REFERENSI}

Anggarawati, D., \& Hakim, S. N. (2018). Kontrol Diri Dan Kecemasan Siswa SMA Dalam Menghadapi Ujian Nasional. Briliant: Jurnal Riset Dan Konseptual, 3(4), 476.

https://doi.org/10.28926/briliant.v3i4.249

Departemen Kesehatan RI. (2013). Laporan Survey Kesehatan Rumah Tangga (SKRT). Harpell, J. V., \& Andrews, J. J. W. (2012). Multi-Informant Test Anxiety Assessment of Adolescents. Psychology, 03(07), 518-524. https://doi.org/10.4236/psych.2012.37075 Hurlock, E. (1992). Psikologi Perkembangan. Erlangga.

Kendall. (2008). Cognitive Behavioral Therapy, Setraline,or a Combination in Childhood Anxiety. The New EnglandJournal of Medicine, 359(26).

Mingers, J., \& Standing, C. (2018). Kent Academic Repository Assessment. Journal of Information Technology, 33(2), 85-104.

Mowbray, T., Jacobs, K., \& Boyle, C. (2015). Validity of the German Test Anxiety Inventory (TAI-G) in an Australian sample. Australian Journal of Psychology, 67(2), 121-129. 
https://doi.org/10.1111/ajpy.12058

Mukhlis, H., \& Koentjoro. (2014). Pelatihan Kebersyukuran untuk Menurunkan Kecemasan Menghadapi Ujian Nasional pada Siswa SMA. Gadjah Mada Journal of International Psychology, 1(3), 203-215.

Nevid, J. S., Rathus, S. A., \& Greene, B. (2013). Psikologi Abnormal. Erlangga.

Putwain, D. (2008). LJMU Research Online. Psychologist, 21(12), 1026-1029.

Rasor, L. T., \& Rasor, R. A. (1998). Test Anxiety and Study Behavior of Community College Students in Relation to Ethnicity, Gender, and Age.

$\mathrm{http}: / / \mathrm{www}$.eric.ed.gov/ERICWebPortal/contentdelivery/servlet/ERICServlet?accno=ED 415942\%5Cnhttp://www.eric.ed.gov/ERICWebPortal/search/recordDetails.jsp?ERICExt Search_SearchValue_0=ED415942\&searchtype=keyword\&ERICExtSearch_SearchType 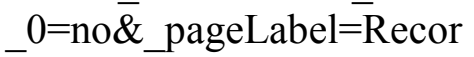

Santrock, J. W. (2011). Life Span Development: Perkembangan Masa Hidup (Ketigabela). Erlangga.

Sari, A. W., Mudrajan, \& Alizamar. (2017). Tingkat Kecemasan Siswa Dalam Menghadapi Ujian Sekolah Ditinjau Dari Jenis Kelamin, Jurusan, dan Daerah Asal Serta Implikasi. Jurnal Bikotetik, 37-72. 